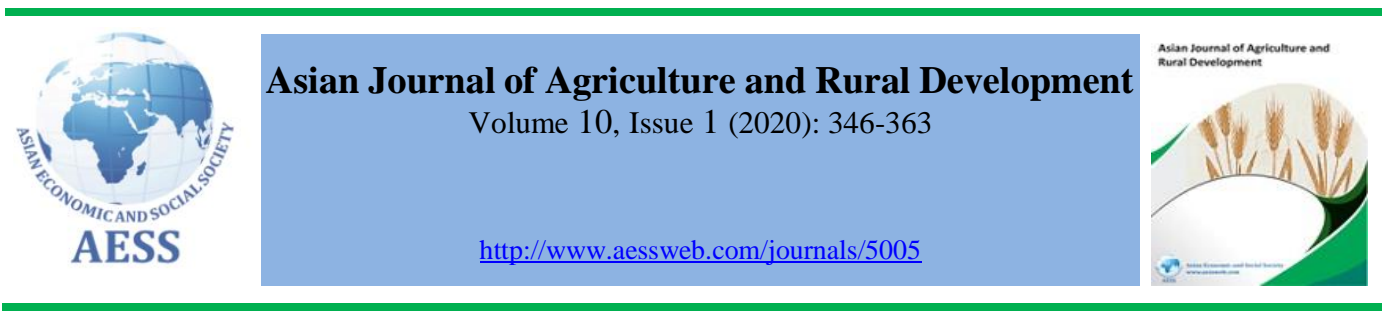

\title{
TERTIARY INSTITUTIONS AND DEVELOPMENT IN RURAL COMMUNITIES: ROLE OF FEDERAL UNIVERSITY OYE-EKITI, EKITI STATE, NIGERIA
}

\author{
Rufus B. Akindola ${ }^{\text {a }}$ \\ Shina J. Ojo ${ }^{b}$
}

\section{ARTICLE HISTORY:}

Received: $25-\mathrm{Feb}-2020$

Accepted: 06-May-2020

Online Available: 10-Jun2020

\section{Keywords:}

Tertiary institutions, Host communities, Rural development, Economic development a Department of Sociology, Federal University Oye-Ekiti, Ekiti State, Nigeria

${ }^{\mathrm{b}}$ The Directorate of Pre-Degree, Federal University Oye-Ekiti, Ekit State, Nigeria

$\checkmark$ boluwaji56@gmail.com (Corresponding author)

\section{Contribution/ Originality}

Despite the establishment of new universities in communities in Nigeria, not enough research has focused on how such universities impact the rural communities. This study is important in that it explored how the presence of tertiary institutions can transform the host communities in terms of the availability of a wide range of choices. The findings of the study will significantly benefit policymakers in the area of rural development.

How to cite: Rufus B. Akindola and Shina J. Ojo (2020). Tertiary institutions and development in rural communities: role of federal university Oye-Ekiti, Ekiti State, Nigeria. Asian Journal of Agriculture and Rural Development, 10(1), 346-363.

(C) 2020 Asian Economic and Social Society. All rights reserved. 


\section{INTRODUCTION}

The contributions of tertiary institutions to host communities' socio-economic development cannot be overemphasized. This is because substantial evidence suggests that rural communities with the presence of tertiary institutions have been transformed both socially and economically. For example, Fatoki (2017) posits that the citing of a tertiary institution in a community has the potential to create employment opportunities for both skilled and unskilled labor which in turn increases the population of the town as a result of migration. This singular factor motivates various communities in Nigeria, including political heavyweights, to lobby for the establishment of tertiary institutions in rural areas within their constituencies.

Higher education remains a major investment in human capital to enhance capabilities. It is also an indispensable ingredient in attaining development, not just in the national economy, but also in communities where such institutions are situated. There is presently a global interest in measuring the impact of tertiary institutions on host communities using social and economic indicators other than pure academic indicators. Nigeria, as a multicultural state formation has over 250 ethnic groups and about 570 Tertiary institutions whose roles and responsibilities transcend the realm of education (Fatoki, 2017; Ehinmowo and Eludoyin, 2010). This is because research activities carried out in tertiary institutions are community-oriented as they are conducted in a manner that the development of host communities is felt and practiced by all stakeholders.

In the perception of Garlick (2005), the association between tertiary institutions and host communities is structural. In other words, tertiary institutions are major economic boosters for host communities essentially because of the opportunity for wealth creation and the flow of commerce. Although wealth creation may be an indicator of economic growth in rural communities, it is not a sufficient condition for the achievement of development. Sen (2001) postulates that the achievement of functioning depends not only on the commodities owned by the person in question, but also on the availability of public goods, and the possibility of using private goods freely provided by the state. The Nobel Laureate further explains that such achievements as being healthy, being well-nourished, being literate, etc. would depend naturally also on the public provisions of health services, medical facilities, educational arrangements, and so on. The underlying motivation behind these assertions is the emphasis on the relationship between economic growth and freedom from oppression, powerlessness, and voicelessness. More explicitly stated, Todaro and Smith (2015), argue that the advantage of economic growth is not that wealth increases happiness, but increases the range of human choices. The bottom line is that true happiness in a rural communityuniversity relationship is only possible when the presence of tertiary institutions provides more viable choices for members of rural communities in terms of access to health care facilities, quality education, and improved standard of living.

In establishing the association between these two variables (universities and development of host communities), Stokes and Coomes (1998), maintain that the economic impacts of tertiary institutions on communities range from knowledge creation and sharing through research and development to the flow of income and expenditure within the community. According to Tanko (2016), while universities provide quality education, they also offer a range of social, economic, and cultural activities to their host communities. However, Nigeria is widely characterized by communities that are primitive when it comes to issues of socio-economic development. This is due to the neglect of rural communities by policymakers, the economic distance of such communities, and lack of basic infrastructure. As such, the government in the recent past has established new tertiary institutions in some of these communities to create wealth and promote rural development. The establishment also aims to meet the needs of a teeming population of youths desiring to gain a higher education degree. Despite the presence of these new universities, however, not enough research has critically examined how such universities impact the local host communities. 
The main objective of this study, therefore, is to examine how rural communities are transformed in terms of the availability of a wide range of choices when tertiary institutions are located in such communities via an empirical study. In this case, it becomes imperative to seek the perception of relevant stakeholders (students, university staff, landlords and business owners) on the impact of the university within the community, taking into cognizance, development indicators such as access to primary education, basic health care facilities and standard of living.

\section{LITERATURE REVIEW}

Since the establishment of Nigeria's Premier University in the late 1950s, several scholars have embarked on a knowledge-journey towards establishing the association between tertiary institutions and host communities. Such ancient scholars include Ayobami (1977), who investigated the physical impact of the University of Ife (Now, Obafemi Awolowo University) on Ile-Ife town. He concluded that the siting of a Tertiary institution in a community creates employment opportunities for both skilled and unskilled labour. Accordingly, this in turn increases the population of the town as a result of people migrating to the area to explore employment opportunities. Also, the development of higher institutions contributes to the development of host communities as well as the surrounding villages in an upward trend (Yu et al., 2015). Florida (2004) shows that the presence of a high-grade university in a community gives it a competitive advantage compared to areas without such institutions. In studying the economic impact of Nigerian tertiary institutions on host communities, Awah (2010) argues that institutions such as University of Ibadan, Obafemi Awolowo University Ile-Ife and University of Port-Harcourt, were situated and named after small settlements many years ago which today have grown into major cities in the country with sufficient infrastructure for development.

In examining the critical role of open universities in the development of countries, Hayward (2006), argues that the attention given to higher education by a nation determines the degree to which the economic benefits will be reaped. Echoing these views, Ali (2010) asserts that open universities in different countries of the world meet the nations' need for stable, peaceful, and progressive communities. Furthermore, Yu et al (2015), examines the role of universities in the development of innovative technology in host communities and agree that the presence of the Tomsk University in Russia has led to rapid development in the Tomsk region, not just in terms of technology but also economically. Similarly, Liu et al. (2016) argue that the rate of urbanization in China has accelerated since the 1990s, and local governments have endeavoured to establish various types of development zones with New Areas, New Towns, and University Towns emerging as new types of urban space. In the future, people from other cities, provinces, and perhaps nations will move to such university towns, and residents will experience positive and negative changes (Zhang et al., 2019). Moreover, these changes will have major impacts on residents, including on their income and livelihood opportunities, as well as to their normal daily life, environment, culture, and infrastructure. To this end, several theories explaining the impact of tertiary institutions on host communities have been propounded. They include the liberalist and professional formation theories. The liberalists, for example, explain that higher education leads to self-realization and social transformation, while on the other hand, the professional formation theory states that universities and other tertiary institutions are providers of expertise and vocational education in both traditional and modern fields (Watson, 2011).

\section{MATERIALS AND METHODS}

The study adopted a random sampling method as well as stratified sampling techniques in the collection of data. The questionnaire was administered to respondents in two Local Government Areas (Oye and Ikole) where the university's major campuses are situated. This was carried out in a supervised group environment. The purpose of the survey was to obtain the views of relevant stakeholders on the university and rural community relationship as it relates to wealth creation and 
development. A total of 321 questionnaires were distributed to students, landlords (locals), university staff members, and business owners out of which $90 \%$ (i.e. 289) were duly-filled and returned. The number of questionnaires was based on the Qualtrics calculator which calculates and determines representative sample size using the following parameters: population size (5000), the margin of error or confidence interval $(+/-5 \%)$, confidence level $(90 \%)$ and standard deviation (0.5). The participants were randomly selected across both LGAs to avoid selection bias.

\subsection{Characteristics of respondents}

The sample included 400 level or final year university students in selected departments (Economics, Peace \& Conflict Resolution, Psychology, Microbiology, Mechanical Engineering, Agricultural Engineering, Soil Science, and English and Literary Studies) from both campuses accounting for $32.7 \%$ of total respondents. University staff members who have worked in the university for five years accounted for $22.1 \%$ while landlords or locals who were residing in the community before the establishment of the university accounted for $22.1 \%$. On the other hand, business owners who had been operating in the community before the establishment of the university accounted for $23.1 \%$ of total respondents. The streamlining in the sample population was occasioned by the need to obtain accurate information from stakeholders who have resided or worked in these communities for at least three years. Over $60 \%$ of student respondents were female while less than $40 \%$ were male as presented in Figure 1. This is because female students were more willing to fill and return questionnaires administered to them than male students.

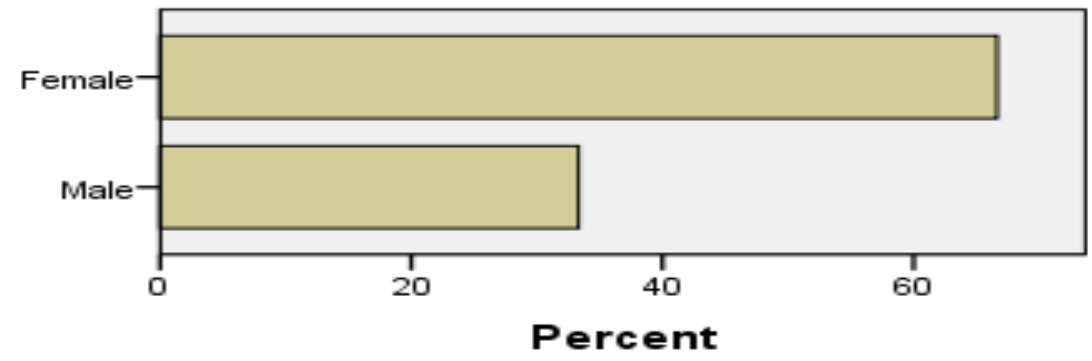

\section{Figure 1: Gender distribution of students}

It must be stated that $78 \%$ of landlords interviewed were male while only $23 \%$ of them were female. Moreover, a high percentage of landlords (74\%) own houses in Oye while only $27 \%$ reported that they own houses in Ikole as evident in Figure 2. This is because Oye community hosts the university's main campus with five (5) faculties, while Ikole community hosts the Faculties of Agriculture and Engineering only.

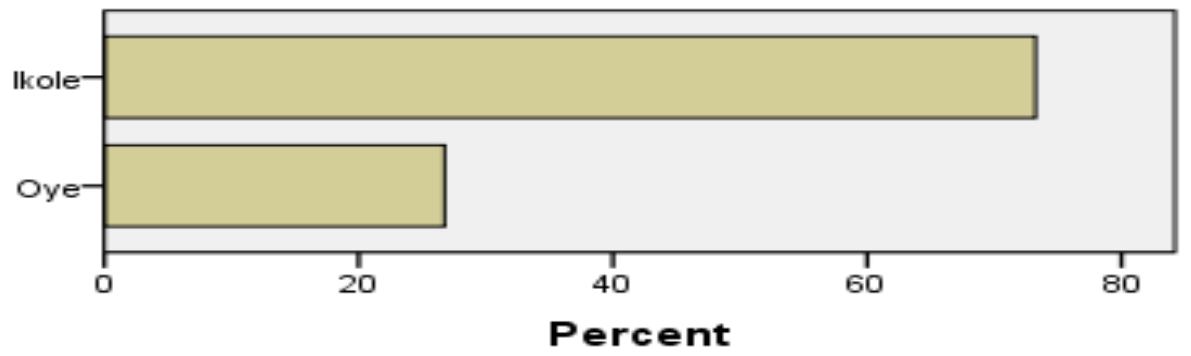

\section{Figure 2: Location of landlords' houses}

It is also interesting to note that majority of business owners interviewed are involved in food business accounting for the major business category of the respondents. Similarly, the majority of business owners operate their businesses within Oye LGA as it hosts five of the university's seven faculties while $33 \%$ operate their businesses within Ikole LGA. On the other hand, 53\% of 
university staff members have worked with the university for more than five years while $48 \%$ have worked for just five years.

\section{FINDINGS AND DISCUSSIONS}

Given that this study pooled information from students, university staff, business owners, and landlords/locals, the income and proportion of it spent within the host communities were analyzed and presented in the following section.

\subsection{Proportion of income earned by students}

Figure 3 indicates that $48 \%$ of respondents earn less than NGN10,000 (27USD), $32 \%$ earn between NGN10,000 (27USD) and NGN25,000 (68USD), 18.1\% earn between NGN26,000 (70USD) and NGN50,000 (136USD) respectively. Only 3\% earn NGN50,000(136USD) and above monthly.

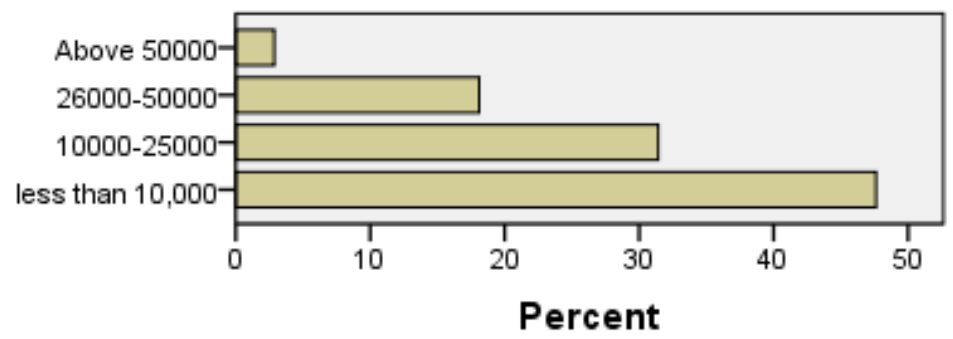

Figure 3: Proportion of income earned by students

\subsection{Percentage of students' income spent in Oye/Ikole}

Figure 4 shows that, of all student respondents, a significant proportion (30\%), spend more than $80 \%$ of their income within Oye/Ikole communities. $25 \%$ spend between $61 \%$ and $80 \%$ of their income. Also, $20 \%$ of the respondents spend between $41 \%$ and $60 \%$ while $16 \%$ spend between $21 \%$ and $40 \%$ with $11 \%$ spending less than $20 \%$ of their income within host communities. Considering these results, it can be observed that more than $90 \%$ spend at least $40 \%$ of their monthly income within Oye/Ikole communities hence, contributing significantly to the creation of wealth. Considering these results, it can be observed that more than $90 \%$ spend at least $40 \%$ of their monthly income within Oye/Ikole communities hence, contributing significantly to the creation of wealth. A study conducted by Fatoki (2017) on a South African University shows that although the majority of university students do not have a written budget, female students are more likely than male students to have a budget. In addition, the study reveals that the majority of university students spend money on groceries and fast food which contributes significantly to the local economy. This is consistent with the findings of the present study and Maslow's hierarchy of needs in his 1943 paper where he listed food, water, and other physiological needs as the basic needs of man.

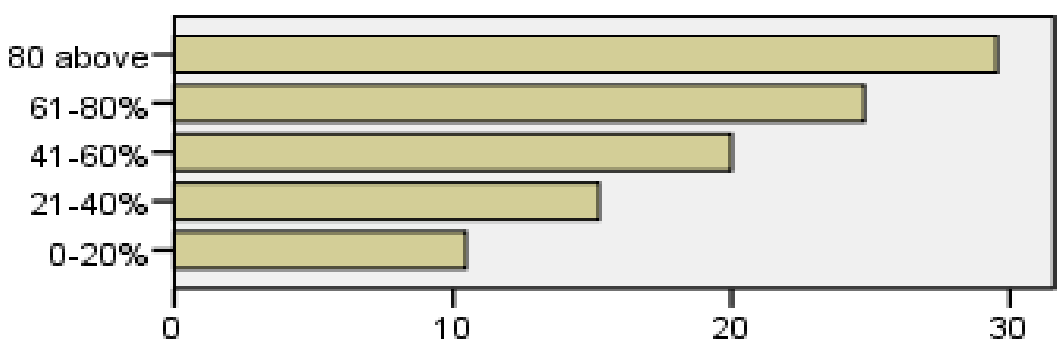

Percent

Figure 4: Percentage of students' income spent in Oye/Ikole 


\subsection{Current monthly income of business owners}

Figure 5 reports the different monthly income category of business owners operating within Oye/Ikole communities since the establishment of the university. It shows that a majority (42\%) of respondents earn between NGN25,000 (68USD) and NGN49,999 (133USD) monthly, 22\% earn between NGN50,000 (136USD) and NGN79,999 (215USD), 18\% earn between NGN80,000 (218USD) and NGN99,999 (270USD), 14\% earn at least NGN100,000 (272USD) per month while a tiny proportion (6\%) earns between NGN10,000 (27USD) and NGN24,999 (65USD) monthly respectively.

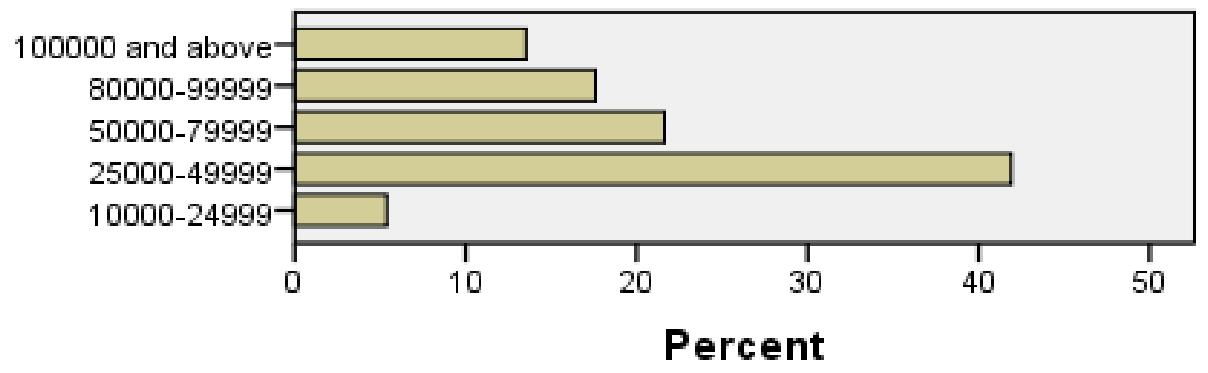

Figure 5: Current monthly income of business owners

\subsection{Monthly income of business owners before the establishment of the university}

Figure 6 shows the income of business owners before the establishment of the university. It reveals that $56 \%$ of them earned between N30,000 (81USD) and N49,999 (133USD). It also shows that $21 \%$ earned between N10,000 (27USD) and N29,000 (79USD) while $24.3 \%$ earned less than N10,000 (27USD) before the university began its operation in 2012. When compared with figure 5 above, it becomes clear that the monthly income of business owners rose significantly as $54 \%$ (i.e. $22 \%+18 \%+14 \%$ ) of them now earn at least N50,000 (136USD) since the establishment of the university indicating an increased possession of wealth for business owners. It must be noted that income can vary based on where a business is located. Arguably, some areas have a higher cost of living than others, and there is more demand for certain products and services in some areas than others (Blakely-Gray, 2020). This explains the differential in the incomes of business owners before the university was located in Oye and Ikole communities when there were little or no economic activities compared to when the university has now been located in the areas.

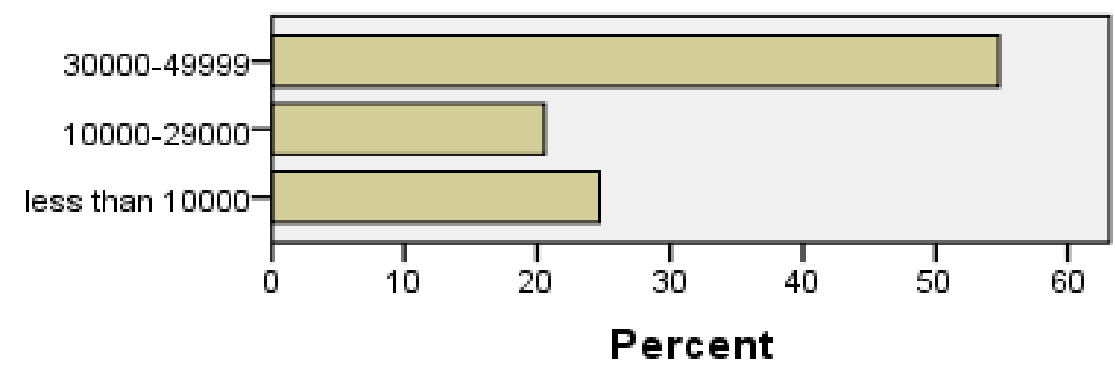

Figure 6: Income of business owners before the establishment of the university

\subsection{The proportion of income spent by university staff members within Oye/Ikole communities}

Figure 7 below shows the proportion of the income of university staff spent within Oye/Ikole communities. It reveals that $51 \%$ of the respondents spend between $41 \%$ and $60 \%$ of their monthly income within these host communities, $29 \%$ spend between $21 \%$ and $40 \%, 11 \%$ spend between $61 \%$ and $80 \%$, while a tiny proportion $(10 \%)$ spend $20 \%$ of their monthly income. 


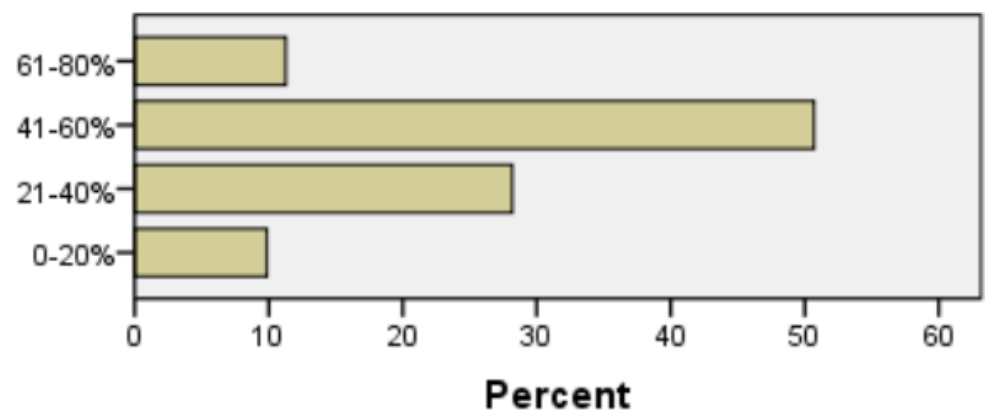

Figure 7: Proportion of the income of university staff

Figure 8 shows the house rent charges of landlords before the establishment of the university while

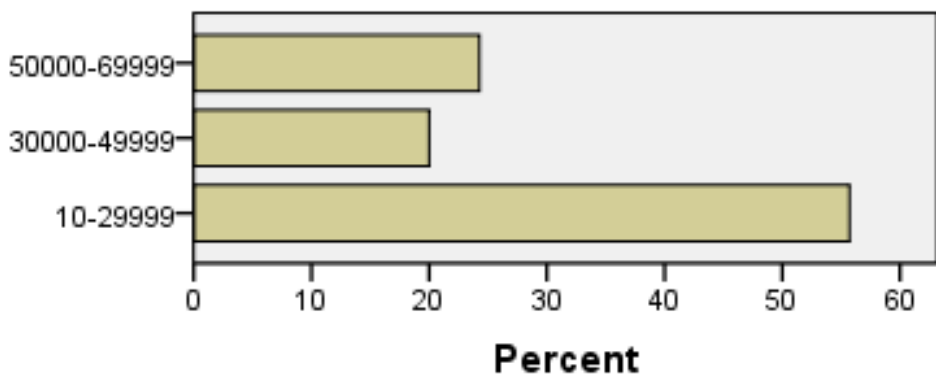

Figure 8: House rent charges of landlords before the establishment of the university

As evident in figure 8 above, 56\% of landlords charged between N10,000 (27USD) and N29,999 (80USD) as house rent, 20\% of them charged between N30,000 (81USD) and N49,999 (133USD), while 24\% charged between N50,000 (136USD) and N69,999 (188USD) for basic single rooms, standard single rooms and self-contained apartments respectively before the establishment of the university.

Figure 9 below shows landlords' rent charges since the establishment of the university. It suggests that $34 \%$ of the landlords still charge between N10,000 (27USD) and N29,999 (79USD), while $66 \%$ charge between N30,000 (81USD) and N49,999 (133USD) for basic single rooms. This reflects an increase of about $100 \%$ in rent charges for basic single rooms since the establishment of the university.

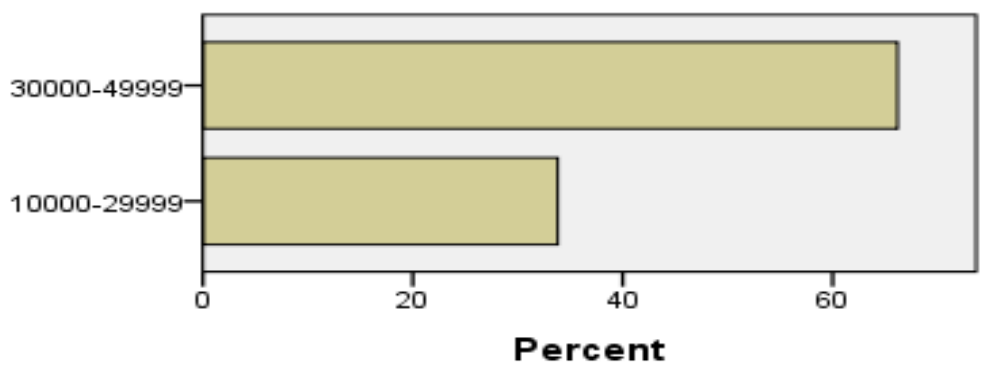

Figure 9: Landlords' current charges for single rooms

Furthermore, the house rent of students upon their admission in 100-level was compared with their rent in 300-level and 400-level as the case may be. The respondents see the presence of the university as the reason for the increase in house rent as more students are being admitted but 
without corresponding accommodation facilities in place thereby creating demand-side inflation (Awah, 2010). Table 1 below summarizes the responses of students with $97.1 \%$ attributing the high rent cost to the presence of the university in the community.

Table 1: Students' responses to high house rent

\begin{tabular}{lc}
\hline Factors & Percent \\
\hline Presence of University & 97.1 \\
Others & 2.9 \\
Total & 100.0 \\
\hline
\end{tabular}

The astronomical rise in house rent as a result of the presence of the university is not surprising given the fact that the establishment of Ladoke Akintola University of Technology (LAUTECH) in Ogbomoso also led to an increase in the movement of people from outside Ogbomoso into the city at an alarming rate. According to Akinyode et al. (2015), the increase in housing demand in Ogbomoso where the institution is situated has increased in the house rental value.

\subsection{Cost of house rent for business owners before the establishment of the university}

The rent paid by business owners before the establishment of the university was also compared with the rent being paid since the establishment of the university. Business owners operating in the two communities before the establishment of the university also agree that the establishment of the university is responsible for the rise in the cost of the rent. However, there are no sufficient accommodation facilities to meet the demands of both the students and other residents. This is summarized in Table 2 . The table shows that $84 \%$ of business owners believe that the presence of the university is the main factor responsible for the increased cost of house rent. These findings are also consistent with the findings of yet another study conducted by Zhang et al. (2019) on a new Chinese university located in the rural community of Yantai. They found that residents (former peasants) consequently experienced a process of urbanization of their community and the local environment. In addition, there was an influx of people from other cities in China, causing social changes and impacts on the local communities.

Table 2: Business owners' responses to high house rent

\begin{tabular}{lc}
\hline Factors & Percent \\
\hline University & 84 \\
Others & 16 \\
Total & 100.0 \\
\hline
\end{tabular}

\subsection{Regression analysis}

In measuring the degree of impact of the university on rent charges in Oye/Ikole communities, the rent charged by landlords ( 7 years ago) was linearly-regressed on their current annual rent. The following tables display the results of the regression analysis:

Table 3: Results of landlords' rent charges before the establishment of the university

\begin{tabular}{llcccccc}
\hline $\begin{array}{l}\text { ANOVA }^{\text {a }} \\
\text { Model }\end{array}$ & & Sum of Squares & Df & Mean Square & P-value & F-value & Adj. $\mathbf{R}^{\mathbf{2}}$ \\
\hline 1 & Regression & 44727123703.879 & 1 & 44727123703.879 & 0.000 & 259.64 & $78.7 \%$ \\
& Residual & 11886425591.896 & 69 & 172267037.564 & & & \\
& Total & 56613549295.775 & 70 & & & & \\
\end{tabular}

The ANOVA table shows the 'P', ' $F$ ', and adj. $\mathrm{R}^{2}$ values for the regression model. This result is statistically significant as P-value is less than 0.0005 and F-value is significantly large. It also shows that the adjusted $\mathrm{R}^{2}$ is $78.7 \%$ which suggests that about $79 \%$ of the variations in the current 
rent charge are affected by rent charges before the presence of the university. In other words, the presence of the university has accounted for much of the increase in house rent even though such accommodation has not been upgraded to modern hostel facilities best-fit for students.

Table 4: Results of current rent charges by landlords

\begin{tabular}{lccc}
\hline Variable & Coefficients & t & P-value \\
\hline $\begin{array}{l}\text { (Constant) } \\
\text { please provide an estimate of your house rent } \\
\text { charges annually before the establishment of the } \\
\text { university/7yrs ago }\end{array}$ & 16755.741 & 6.048 & 0.000 \\
\hline
\end{tabular}

The table above indicates that the regression model is one that is statistically significant as P-value is less than 0.005 . It also shows that the minimum annual cost of house rent charged by landlords for a room is around N16,755 (45USD) and that an N1 (0.00256USD) increase or decrease in house rent charges before the establishment of the university will lead to an N1.309 (0.00335USD) increase or decrease in the current house rent charges respectively. To predict the cost of house rent levied by landlords, the regression equation can be specified as follows:

Landlords' rent charge now $=16755+1.309$ (house rent levy before the establishment of the university)

\subsection{Impact of the university on the development of Oye/Ikole communities}

To empirically determine the perception of locals, business owners, university staff members, and students on the economic impact of the university within the two communities, key questions were asked and data collected were analyzed and presented in the perception tables below.

Table 5 above shows a larger percentage of students (90.4\%) between 200-Level and 400-Level agree that the presence of the university has increased the number of large businesses in the communities while about $5.7 \%$ disagree and $1 \%$ undecided. Similarly, $85.7 \%$ of the students believe that the presence of the university has led to the establishment of more banks in the host communities, while $10.5 \%$ disagree with the statement and $1.9 \%$ undecided. Also, $95.2 \%$ of students agree that the number of petty businesses has increased since their admission into the university while $1.9 \%$ disagrees and $2.9 \%$ undecided. In contrast, $75.1 \%$ of students disagree that the presence of the university has led to an improved road network in the host communities while $23.8 \%$ of students agree with the statement and just $1.0 \%$ undecided. While a proportion of $59.3 \%$ of students agree that there has been an improved power supply in the host communities,31.5\% disagree and $9.5 \%$ undecided. Furthermore, $91.4 \%$ of students agree that modern hostels are increasingly being built as a result of the presence of the university, $2.9 \%$ disagree while $4.8 \%$ are undecided. Also, while $86.6 \%$ agree that pit and bush toilets are no longer popular in the host communities as a result of the presence of the university, $8.6 \%$ disagree with the statement and $4.8 \%$ undecided. Finally, about $95.2 \%$ of students agree that the presence of the university has led to an overall improvement in the local economy of host communities in terms of wealth creation, $2.9 \%$ disagree and $1.9 \%$ are undecided. These findings reflect an assertion by Fatoki (2017) that universities can drive development in a community by using Osun State University as a case study. 
Table 5: Students' perception of the university's presence and development of Oye/Ikole

\begin{tabular}{|c|c|c|c|c|c|c|c|c|c|}
\hline No. & Questions & SA & A & $\mathbf{U}$ & D & SD & Mean & S. D & Remark \\
\hline 1 & $\begin{array}{l}\text { Number of large businesses has increased since } \\
\text { your admission into the university }\end{array}$ & $\begin{array}{c}22.9 \% \\
(24)\end{array}$ & $\begin{array}{c}70.5 \% \\
(74)\end{array}$ & $\begin{array}{l}1 \% \\
(1)\end{array}$ & $\begin{array}{c}3.8 \% \\
(4)\end{array}$ & $\begin{array}{c}1.9 \% \\
(2)\end{array}$ & 4.09 & 0.748 & Agree \\
\hline 2 & $\begin{array}{l}\text { The presence of the university has led to a } \\
\text { consistent increased cost of rent in your } \\
\text { community }\end{array}$ & $\begin{array}{l}21 \% \\
(20)\end{array}$ & $\begin{array}{l}76.2 \% \\
(80)\end{array}$ & $\begin{array}{c}1.9 \% \\
(2)\end{array}$ & $\begin{array}{l}0 \% \\
(0)\end{array}$ & $\begin{array}{l}1 \% \\
(1)\end{array}$ & 4.16 & 0.539 & Agree \\
\hline 3 & $\begin{array}{l}\text { The presence of the university has led to a } \\
\text { consistent increased cost of transportation in } \\
\text { your community }\end{array}$ & $\begin{array}{c}12.4 \% \\
(13)\end{array}$ & $\begin{array}{c}68.6 \% \\
(72)\end{array}$ & $\begin{array}{l}8.6 \% \\
(9)\end{array}$ & $\begin{array}{c}10.5 \% \\
(11)\end{array}$ & $\begin{array}{l}0 \% \\
(0)\end{array}$ & 3.83 & 0.778 & Agree \\
\hline 4 & $\begin{array}{l}\text { The presence of the university has led to the } \\
\text { establishment of more banks in your community }\end{array}$ & $\begin{array}{c}9.5 \% \\
(10)\end{array}$ & $\begin{array}{c}76.2 \% \\
(80)\end{array}$ & $\begin{array}{l}1.9 \% \\
(2)\end{array}$ & $\begin{array}{l}8.6 \% \\
(9)\end{array}$ & $\begin{array}{l}1.9 \% \\
(2)\end{array}$ & 3.84 & 0.789 & Agree \\
\hline 5 & $\begin{array}{l}\text { Number of petty businesses has increased since } \\
\text { your admission into the university }\end{array}$ & $\begin{array}{c}13.3 \% \\
(14)\end{array}$ & $\begin{array}{c}81.9 \% \\
(86)\end{array}$ & $\begin{array}{l}2.9 \% \\
(3)\end{array}$ & $\begin{array}{c}1.9 \% \\
(2)\end{array}$ & $\begin{array}{l}0 \% \\
(0)\end{array}$ & 4.07 & 0.486 & Agree \\
\hline 6 & $\begin{array}{l}\text { The presence of the university has led to an } \\
\text { improved road network in your community }\end{array}$ & $\begin{array}{l}6.7 \% \\
(7)\end{array}$ & $\begin{array}{c}17.1 \% \\
(18)\end{array}$ & $\begin{array}{c}1.0 \% \\
(1)\end{array}$ & $\begin{array}{c}72.4 \% \\
(76)\end{array}$ & $\begin{array}{l}2.9 \% \\
(3)\end{array}$ & 2.52 & 1.029 & Disagree \\
\hline 7 & $\begin{array}{l}\text { The presence of the university has led to an } \\
\text { improved power supply in your community }\end{array}$ & $\begin{array}{l}6.7 \% \\
(7)\end{array}$ & $\begin{array}{l}52.4 \% \\
(55)\end{array}$ & $\begin{array}{c}9.5 \% \\
(10)\end{array}$ & $\begin{array}{c}28.6 \% \\
(30)\end{array}$ & $\begin{array}{l}2.9 \% \\
(3)\end{array}$ & 3.31 & 1.050 & Agree \\
\hline 8 & $\begin{array}{l}\text { Modern houses are increasingly being built due } \\
\text { to the presence of the university }\end{array}$ & $\begin{array}{c}14.3 \% \\
(15)\end{array}$ & $\begin{array}{c}78.1 \% \\
(82)\end{array}$ & $\begin{array}{c}4.8 \% \\
(5)\end{array}$ & $\begin{array}{l}1 \% \\
(1)\end{array}$ & $\begin{array}{l}1.9 \% \\
(2)\end{array}$ & 4.05 & 0.564 & Agree \\
\hline 9 & $\begin{array}{l}\text { Pit latrines, bush toilets etc. are no longer } \\
\text { popular in your community due to the presence } \\
\text { of the university }\end{array}$ & $\begin{array}{l}7.6 \% \\
(8)\end{array}$ & $\begin{array}{l}79.0 \% \\
(83)\end{array}$ & $\begin{array}{l}4.8 \% \\
(5)\end{array}$ & $\begin{array}{l}6.7 \% \\
(7)\end{array}$ & $\begin{array}{l}1.9 \% \\
(2)\end{array}$ & 3.86 & 0.700 & Agree \\
\hline 10 & $\begin{array}{l}\text { Some students stay behind after graduation to } \\
\text { start up business ventures }\end{array}$ & $\begin{array}{l}7.6 \% \\
(8)\end{array}$ & $\begin{array}{l}81.0 \% \\
(85)\end{array}$ & $\begin{array}{c}9.5 \% \\
(10)\end{array}$ & $\begin{array}{l}1 \% \\
(1)\end{array}$ & $\begin{array}{l}1 \% \\
(1)\end{array}$ & 3.93 & 0.542 & Agree \\
\hline 11 & $\begin{array}{l}\text { Businesses established by students during their } \\
\text { stay on campus are sustained and are } \\
\text { contributing to the local economy }\end{array}$ & $\begin{array}{c}11.4 \% \\
(12)\end{array}$ & $\begin{array}{c}82.9 \% \\
(87)\end{array}$ & $\begin{array}{l}4.8 \% \\
(5)\end{array}$ & $\begin{array}{l}0 \% \\
(0)\end{array}$ & $\begin{array}{l}1 \% \\
(1)\end{array}$ & 4.04 & 0.499 & Agree \\
\hline 12 & $\begin{array}{l}\text { The presence of the university has led to an } \\
\text { overall improvement in the local economy }\end{array}$ & $\begin{array}{c}13.3 \% \\
(14)\end{array}$ & $\begin{array}{l}81.9 \% \\
(86)\end{array}$ & $\begin{array}{c}1.9 \% \\
(2) \\
\end{array}$ & $\begin{array}{l}0 \% \\
(0)\end{array}$ & $\begin{array}{l}2.9 \% \\
(3)\end{array}$ & 4.03 & 0.642 & Agree \\
\hline
\end{tabular}

Source: Authors' calculations from survey data (2019) 
Table 6 shows that $95.8 \%$ of landlords agree that modern houses are being built compared to local houses predominant before the establishment of the university while $1.4 \%$ disagree and $2.8 \%$ undecided. Moreover, while $91.6 \%$ of landlords agree that the number of land agents has risen precipitously since the establishment of the university, $8.5 \%$ are undecided. Around $94.3 \%$ of landlords agree that abandoned houses have been renovated since the establishment of the university, while $5.6 \%$ are undecided. Of note is the fact that $98.6 \%$ of landlords agree that support services, such as cleaners and caretakers, have increased, $1.4 \%$ appears undecided. In contrast, $57.7 \%$ of landlords disagree that there will be more hostels than family residences as a result of the presence of the university, $36.7 \%$ however agree while $5.6 \%$ are undecided. These findings are consistent with the findings of Akinyode et al. (2015) which show that the presence of the tertiary institutions in a community would drive commerce and attract more population of people seeking greener pastures.

Table 7 shows that $93.1 \%$ of business owners agree that the presence of the university has led to a steady increase in their sales over time, while the remaining $6.9 \%$ disagree with the statement. Also, $89.2 \%$ agree that the presence of the university has led to a consistent increase in the number of sellers trading in the same commodities, while $6.8 \%$ disagree and about $4.1 \%$ undecided. $93.3 \%$ of business owners agree strongly that the presence of the university has improved the purchase of daily consumables, $5.4 \%$ disagree leaving $1.4 \%$ undecided. Similarly, $93.3 \%$ agree that the presence of the university has increased the number of buyers of their commodities, $6.8 \%$ disagree with the statement. 93.2\% agree that the profit margin for their businesses has risen significantly since the establishment of the university while 5.2\% disagree leaving just $1.4 \%$ undecided. Furthermore, $64.9 \%$ agree that the presence of the university has provided their businesses with cheap labour (i.e. students who are willing to work part-time for little wages), $31.1 \%$ disagree while $4.1 \%$ are undecided. Moreover, about $99 \%$ completely agree that the quality of goods and services provided by businesses has improved since the establishment of the university leaving just 1.4 undecided. Also, an estimated $93.3 \%$ of business owners agree that the presence of the university has caused their businesses to enjoy increased returns to scale, $4.1 \%$ disagree, and $2.7 \%$ undecided. Also, a combined $92.0 \%$ of business owners agree that most part-time business operators went fulltime after the establishment of the university, 5.4\% disagree, and $2.7 \%$ undecided. Similarly, while $94.6 \%$ of the respondents agree that menial business owners such as bricklayers are increasingly being demanded due to the presence of the university, 5.4\% however disagree. Fatoki (2017) has argued that institutions of higher learning which are located in the community can be good assets for economic growth and be of great service to the business community. In a few years to this time and given the current rapid development, both Oye and Ikole communities could be home to a host of local and foreign companies. 
Table 6: Landlords' perception of the university's presence and development of Oye/Ikole

\begin{tabular}{|c|c|c|c|c|c|c|c|c|c|}
\hline No. & Questions & SA & $\mathbf{A}$ & $\overline{\mathbf{U}}$ & D & SD & Mean & S. D & Remark \\
\hline 1 & $\begin{array}{l}\text { The presence of the university has led to an } \\
\text { increased annual house rent }\end{array}$ & $\begin{array}{c}95.8 \% \\
(68)\end{array}$ & $\begin{array}{c}4.2 \% \\
(3)\end{array}$ & $\begin{array}{c}0 \\
(0 \%)\end{array}$ & $\begin{array}{c}0 \\
(0 \%)\end{array}$ & $\begin{array}{c}0 \\
(0 \%)\end{array}$ & 4.96 & 0.203 & Agree \\
\hline 2 & $\begin{array}{l}\text { There has been an increase in the number of } \\
\text { houses placed on rental since the establishment } \\
\text { of the university }\end{array}$ & $\begin{array}{l}83.1 \% \\
(59)\end{array}$ & $\begin{array}{c}15.5 \% \\
(11)\end{array}$ & $\begin{array}{c}1 \\
(1.4 \%)\end{array}$ & $\begin{array}{c}0 \\
(0 \%)\end{array}$ & $\begin{array}{c}0 \\
(0 \%)\end{array}$ & 4.82 & 0.425 & Agree \\
\hline 3 & $\begin{array}{l}\text { The number of landlords has increased since the } \\
\text { establishment of the university }\end{array}$ & $\begin{array}{l}85.9 \% \\
(61)\end{array}$ & $\begin{array}{l}9.9 \% \\
(7)\end{array}$ & $\begin{array}{l}4.2 \% \\
(3)\end{array}$ & $\begin{array}{l}0 \% \\
(0)\end{array}$ & $\begin{array}{l}0 \% \\
(0)\end{array}$ & 4.82 & 0.487 & Agree \\
\hline 4 & $\begin{array}{l}\text { The number of people renting houses has } \\
\text { increased since the establishment of the } \\
\text { university }\end{array}$ & $\begin{array}{l}85.9 \% \\
(61)\end{array}$ & $\begin{array}{l}14.1 \% \\
(10)\end{array}$ & $\begin{array}{l}0 \% \\
(0)\end{array}$ & $\begin{array}{l}0 \% \\
(0)\end{array}$ & $\begin{array}{l}0 \% \\
(0)\end{array}$ & 4.86 & 0.350 & Agree \\
\hline 5 & $\begin{array}{l}\text { Modern hostels are being built in contrast to } \\
\text { local houses predominant before the } \\
\text { establishment of the university }\end{array}$ & $\begin{array}{l}84.5 \% \\
(60)\end{array}$ & $\begin{array}{l}11.3 \% \\
(8)\end{array}$ & $\begin{array}{l}2.8 \% \\
(2)\end{array}$ & $\begin{array}{l}0 \% \\
(0)\end{array}$ & $\begin{array}{l}1.4 \% \\
(1)\end{array}$ & 4.71 & 0.637 & Agree \\
\hline 6 & $\begin{array}{l}\text { House owners are usually left with no choice } \\
\text { than to persuade students to rent their houses }\end{array}$ & $\begin{array}{l}25.4 \% \\
(18)\end{array}$ & $\begin{array}{l}5.6 \% \\
(4)\end{array}$ & $\begin{array}{l}4.2 \% \\
(3)\end{array}$ & $\begin{array}{l}0 \% \\
(0)\end{array}$ & $\begin{array}{l}64.8 \% \\
(46)\end{array}$ & 2.27 & 1.781 & Disagree \\
\hline 7 & $\begin{array}{l}\text { Number of land agents has risen significantly } \\
\text { since the establishment of the university }\end{array}$ & $\begin{array}{l}81.7 \% \\
(58)\end{array}$ & $\begin{array}{l}9.9 \% \\
(7)\end{array}$ & $\begin{array}{l}8.5 \% \\
(6)\end{array}$ & $\begin{array}{l}0 \% \\
(0)\end{array}$ & $\begin{array}{l}0 \% \\
(0)\end{array}$ & 4.73 & 0.608 & Agree \\
\hline 8 & $\begin{array}{l}\text { Abandoned houses have been renovated due to } \\
\text { the presence of the university }\end{array}$ & $\begin{array}{l}87.3 \% \\
(62)\end{array}$ & $\begin{array}{l}7.0 \% \\
(5)\end{array}$ & $\begin{array}{l}5.6 \% \\
(4)\end{array}$ & $\begin{array}{l}0 \% \\
(0)\end{array}$ & $0 \%$ & 4.82 & 0.516 & Agree \\
\hline 9 & $\begin{array}{l}\text { Support services such as cleaners and caretakers } \\
\text { are in high demand due to the presence of the } \\
\text { university }\end{array}$ & $\begin{array}{l}80.3 \% \\
(57)\end{array}$ & $\begin{array}{c}18.3 \% \\
(13)\end{array}$ & $\begin{array}{l}1.4 \% \\
(1)\end{array}$ & $\begin{array}{l}0 \% \\
(0)\end{array}$ & $\begin{array}{l}0 \% \\
(0)\end{array}$ & 4.79 & 0.445 & Agree \\
\hline 10 & $\begin{array}{l}\text { There will be more hostels than family residence } \\
\text { in the future due to the presence of the university }\end{array}$ & $\begin{array}{c}25.4 \% \\
(18)\end{array}$ & $\begin{array}{c}11.3 \% \\
(8)\end{array}$ & $\begin{array}{c}5.6 \% \\
(4)\end{array}$ & $\begin{array}{c}35.2 \% \\
(25)\end{array}$ & $\begin{array}{c}22.5 \% \\
(16)\end{array}$ & 2.82 & 1.543 & Disagree \\
\hline
\end{tabular}

Source: Authors' calculations from survey data (2019) 
Table 7: Perception of business owners on the university's presence and development in Oye/Ikole

\begin{tabular}{|c|c|c|c|c|c|c|c|c|c|}
\hline No. & Statements & SA & $\mathbf{A}$ & $\mathbf{U}$ & D & SD & Mean & S. D & Remark \\
\hline 1 & $\begin{array}{l}\text { The presence of the university has led to a steady } \\
\text { increase in your sales over time }\end{array}$ & $\begin{array}{c}82.4 \% \\
(61)\end{array}$ & $\begin{array}{c}10.8 \% \\
(8)\end{array}$ & $\begin{array}{l}0 \% \\
(0)\end{array}$ & $\begin{array}{l}5.4 \% \\
(4)\end{array}$ & $\begin{array}{c}1.4 \% \\
(1)\end{array}$ & 4.68 & 0.846 & Agree \\
\hline 2 & $\begin{array}{l}\text { The presence of the university has led to a steady } \\
\text { increase in the number of sellers trading in the } \\
\text { same commodities }\end{array}$ & $\begin{array}{l}75.7 \% \\
(56)\end{array}$ & $\begin{array}{c}13.5 \% \\
(10)\end{array}$ & $\begin{array}{l}4.1 \% \\
(3)\end{array}$ & $\begin{array}{c}5.4 \% \\
(4)\end{array}$ & $\begin{array}{c}1.4 \% \\
(1)\end{array}$ & 4.57 & 0.908 & Agree \\
\hline 3 & $\begin{array}{l}\text { The presence of the University has led to an } \\
\text { increase in the purchase of daily consumables }\end{array}$ & $\begin{array}{l}78.4 \% \\
(58)\end{array}$ & $\begin{array}{c}14.9 \% \\
(11)\end{array}$ & $\begin{array}{l}1.4 \% \\
(1)\end{array}$ & $\begin{array}{c}5.4 \% \\
(4)\end{array}$ & $\begin{array}{l}0 \% \\
(0)\end{array}$ & 4.66 & 0.763 & Agree \\
\hline 4 & $\begin{array}{l}\text { The presence of the university has increased the } \\
\text { number of buyers of your commodities }\end{array}$ & $\begin{array}{c}70.3 \% \\
(52)\end{array}$ & $\begin{array}{c}23.0 \% \\
(17)\end{array}$ & $\begin{array}{l}0 \% \\
(0)\end{array}$ & $\begin{array}{c}6.8 \% \\
(5)\end{array}$ & $\begin{array}{l}0 \% \\
(0)\end{array}$ & 4.57 & 0.812 & Agree \\
\hline 5 & $\begin{array}{l}\text { The purchase of luxury goods has increased over } \\
\text { time since the establishment of the university }\end{array}$ & $\begin{array}{c}73.0 \% \\
(54)\end{array}$ & $\begin{array}{c}21.6 \% \\
(16)\end{array}$ & $\begin{array}{c}1.4 \% \\
(1)\end{array}$ & $\begin{array}{c}2.7 \% \\
(2)\end{array}$ & $\begin{array}{c}1.4 \% \\
(1)\end{array}$ & 4.62 & 0.771 & Agree \\
\hline 6 & $\begin{array}{l}\text { Profit margin for your business has risen } \\
\text { significantly since the establishment of the } \\
\text { university }\end{array}$ & $\begin{array}{l}71.6 \% \\
(53)\end{array}$ & $\begin{array}{c}21.6 \% \\
(16)\end{array}$ & $\begin{array}{c}1.4 \% \\
(1)\end{array}$ & $\begin{array}{l}4.1 \% \\
(3)\end{array}$ & $\begin{array}{c}1.1 \% \\
(1)\end{array}$ & 4.58 & 0.828 & Agree \\
\hline 7 & $\begin{array}{l}\text { The presence of the university has provided your } \\
\text { business with cheap labor e.g. students who work } \\
\text { part time }\end{array}$ & $\begin{array}{c}44.6 \% \\
(33)\end{array}$ & $\begin{array}{c}20.3 \% \\
(15)\end{array}$ & $\begin{array}{l}4.1 \% \\
(3)\end{array}$ & $\begin{array}{c}23.0 \% \\
(17)\end{array}$ & $\begin{array}{l}8.1 \% \\
(6)\end{array}$ & 3.70 & 1.440 & Agree \\
\hline 8 & $\begin{array}{l}\text { Quality of goods and services provided by } \\
\text { businesses has improved since the establishment of } \\
\text { the university }\end{array}$ & $\begin{array}{c}81.1 \% \\
(60)\end{array}$ & $\begin{array}{c}17.6 \% \\
(13)\end{array}$ & $\begin{array}{c}1.4 \% \\
(1)\end{array}$ & $\begin{array}{l}0 \% \\
(0)\end{array}$ & $\begin{array}{l}0 \% \\
(0)\end{array}$ & 4.80 & 0.437 & Agree \\
\hline 9 & Businesses now enjoy increasing returns to scale & $\begin{array}{l}70.3 \% \\
(52)\end{array}$ & $\begin{array}{c}23.0 \% \\
(17)\end{array}$ & $\begin{array}{l}2.7 \% \\
(2)\end{array}$ & $\begin{array}{l}4.1 \% \\
(3)\end{array}$ & $\begin{array}{l}0 \% \\
(0)\end{array}$ & 4.59 & 0.739 & Agree \\
\hline 10 & $\begin{array}{l}\text { Most part-time business operators went full-time } \\
\text { after the establishment of the university }\end{array}$ & $\begin{array}{c}68.9 \% \\
(51)\end{array}$ & $\begin{array}{c}23.0 \% \\
(17)\end{array}$ & $\begin{array}{l}2.7 \% \\
(2)\end{array}$ & $\begin{array}{l}5.4 \% \\
(4)\end{array}$ & $\begin{array}{l}0 \% \\
(0)\end{array}$ & 4.55 & 0.796 & Agree \\
\hline 11 & $\begin{array}{l}\text { Menial business owners such as bricklayers are } \\
\text { increasingly demanded due to the presence of the } \\
\text { university }\end{array}$ & $\begin{array}{l}74.3 \% \\
(55)\end{array}$ & $\begin{array}{l}20.3 \% \\
(15)\end{array}$ & $\begin{array}{l}0 \% \\
(0)\end{array}$ & $\begin{array}{l}2.7 \% \\
(2)\end{array}$ & $\begin{array}{c}2.7 \% \\
(2)\end{array}$ & 4.61 & 0.857 & Agree \\
\hline
\end{tabular}

Source: Authors' calculations from survey data (2019) 
Table 8 above presents the perception of university staff members on the impact of the university on Oye/Ikole communities. It shows that $81.7 \%$ agree they have invested in the building of hostels within the host communities while $18.3 \%$ disagree. Also, $77.5 \%$ agree that Oye and Ikole can become major commercial towns as a result of the presence of the university while $19.8 \%$ disagree and $2.8 \%$ undecided. Similarly, $80.3 \%$ agree that the majority of the university staff members reside within the community while $9.9 \%$ disagree and $9.9 \%$ undecided. As evident in the table, $76 \%$ agree that university staff members have invested in different business ventures within the host communities, $7 \%$ disagree, and $16.9 \%$ undecided. About $79 \%$ of university staff members agree that they spend most of their monthly income within the host communities while $4.2 \%$ disagree and $16.9 \%$ undecided. Also, $67.7 \%$ agree that staff members enroll their children or wards in schools within the host communities while only $9.8 \%$ disagree and $22.5 \%$ undecided. In contrast, $54.9 \%$ disagree that staff members operate bank accounts within the host communities while $29.6 \%$ agree and $15.5 \%$ are undecided.

The findings from this study are consistent with the existing literature. For example, Kemiki et al. (2016); Patrick and Ijah (2020) agree that the location of a tertiary institution in a community leads to an increase in wealth creation and flow, including physical development of host communities in terms of construction of new buildings as hostel accommodation. However, this does not directly translate to an improved standard of living for the people in such areas as wealth is not a basic condition for improved living standards but the availability of viable choices. While the establishment of the university provides the host communities with informal employment opportunities, there is the absence of quality primary education facilities, quality basic health care facilities (except the university's health center), good road networks, and a quality supply of power despite the presence of the university. 
Table 8: Perception of University staff members on the university's presence and development in Oye/Ikole

\begin{tabular}{|c|c|c|c|c|c|c|c|c|c|}
\hline No. & $\begin{array}{c}\text { Statement } \\
\end{array}$ & SA & A & $\mathbf{U}$ & D & SD & Mean & S. D & Remark \\
\hline 1 & $\begin{array}{l}\text { Staff members have invested in the building of } \\
\text { hostels }\end{array}$ & $\begin{array}{c}62.0 \% \\
(44)\end{array}$ & $\begin{array}{c}19.7 \% \\
(14)\end{array}$ & $\begin{array}{l}0 \% \\
(0)\end{array}$ & $\begin{array}{c}1.4 \% \\
(1)\end{array}$ & $\begin{array}{c}16.9 \% \\
(12)\end{array}$ & 4.08 & 1.490 & Agree \\
\hline 2 & $\begin{array}{l}\text { Oye and Ikole both have the potential for major } \\
\text { commercial towns as a result of the University }\end{array}$ & $\begin{array}{c}49.3 \% \\
(35)\end{array}$ & $\begin{array}{l}28.2 \% \\
(20)\end{array}$ & $\begin{array}{l}2.8 \% \\
(2)\end{array}$ & $\begin{array}{c}11.3 \% \\
(8)\end{array}$ & $\begin{array}{l}8.5 \% \\
(6)\end{array}$ & 3.99 & 1.325 & Agree \\
\hline 3 & $\begin{array}{l}\text { Some of the university staff own or manage a } \\
\text { business that thrives due to the presence of the } \\
\text { University }\end{array}$ & $\begin{array}{l}39.4 \% \\
(28)\end{array}$ & $\begin{array}{l}32.4 \% \\
(23)\end{array}$ & $\begin{array}{l}14.1 \% \\
(10)\end{array}$ & $\begin{array}{c}14.1 \% \\
(10)\end{array}$ & $\begin{array}{l}0 \% \\
(0)\end{array}$ & 3.97 & 1.055 & Agree \\
\hline 4 & $\begin{array}{l}\text { Majority of the university staff are resident } \\
\text { within the host communities }\end{array}$ & $\begin{array}{l}49.3 \% \\
(35)\end{array}$ & $\begin{array}{l}31.0 \% \\
(22)\end{array}$ & $\begin{array}{l}9.9 \% \\
(7)\end{array}$ & $\begin{array}{l}8.5 \% \\
(6)\end{array}$ & $\begin{array}{l}1.4 \% \\
(1)\end{array}$ & 4.18 & 1.019 & Agree \\
\hline 5 & $\begin{array}{l}\text { University staff members have invested in } \\
\text { different business ventures within the host } \\
\text { communities }\end{array}$ & $\begin{array}{l}38.0 \% \\
(27)\end{array}$ & $\begin{array}{l}38.0 \% \\
(27)\end{array}$ & $\begin{array}{l}16.9 \% \\
(12)\end{array}$ & $\begin{array}{l}4.2 \% \\
(3)\end{array}$ & $\begin{array}{l}2.8 \% \\
(2)\end{array}$ & 4.04 & 0.992 & Agree \\
\hline 6 & $\begin{array}{l}\text { Staff members spend most of their income within } \\
\text { the host communities }\end{array}$ & $\begin{array}{c}25.4 \% \\
(18)\end{array}$ & $\begin{array}{c}53.5 \% \\
(38)\end{array}$ & $\begin{array}{c}16.9 \% \\
(12)\end{array}$ & $\begin{array}{l}4.2 \% \\
(3)\end{array}$ & $\begin{array}{l}0 \% \\
(0)\end{array}$ & 4.00 & 0.775 & Agree \\
\hline 7 & $\begin{array}{l}\text { Staff members are more willing to reside within } \\
\text { the host communities. }\end{array}$ & $\begin{array}{l}29.6 \% \\
(21)\end{array}$ & $\begin{array}{c}35.2 \% \\
(25)\end{array}$ & $\begin{array}{l}21.1 \% \\
(15)\end{array}$ & $\begin{array}{l}5.6 \% \\
(4)\end{array}$ & $\begin{array}{l}8.5 \% \\
(6)\end{array}$ & 3.72 & 1.197 & Agree \\
\hline 8 & $\begin{array}{l}\text { Staff members patronize business owners within } \\
\text { the communities }\end{array}$ & $\begin{array}{c}46.5 \% \\
(33)\end{array}$ & $\begin{array}{c}47.9 \% \\
(34)\end{array}$ & $\begin{array}{l}4.2 \% \\
(3)\end{array}$ & $\begin{array}{l}1.4 \% \\
(1)\end{array}$ & $\begin{array}{l}0 \% \\
(0)\end{array}$ & 4.39 & 0.643 & Agree \\
\hline 9 & $\begin{array}{l}\text { Staff members enroll their children/wards in } \\
\text { schools within the host communities }\end{array}$ & $\begin{array}{c}42.3 \% \\
(30)\end{array}$ & $\begin{array}{c}25.4 \% \\
(18)\end{array}$ & $\begin{array}{c}22.5 \% \\
(16)\end{array}$ & $\begin{array}{l}4.2 \% \\
(3)\end{array}$ & $\begin{array}{l}5.6 \% \\
(4)\end{array}$ & 3.94 & 1.157 & Agree \\
\hline 10 & $\begin{array}{l}\text { Staff members operate bank accounts within the } \\
\text { host communities }\end{array}$ & $\begin{array}{c}12.7 \% \\
(9) \\
\end{array}$ & $\begin{array}{c}16.9 \% \\
(12) \\
\end{array}$ & $\begin{array}{c}15.5 \% \\
(11) \\
\end{array}$ & $\begin{array}{c}5.6 \% \\
(4) \\
\end{array}$ & $\begin{array}{c}49.3 \% \\
(35) \\
\end{array}$ & 2.38 & 1.534 & Disagree \\
\hline
\end{tabular}

Source: Authors' calculations from survey data (2019) 


\section{CONCLUSION AND RECOMMENDATION}

The main objective of this study has been to examine how rural communities are transformed in terms of the availability of a wide range of choices when tertiary institutions are located in such communities particularly the creation of wealth through various economic activities. From the findings discussed earlier, it is confirmed that the presence of the university in the two communities of Oye and Ikole has increased the number of Small and Medium Scale Enterprises (SMSEs), personal income, household \& personal expenditure, including house rent charges which eventually have led to an improvement in the local economy. Business owners who are engaged inside jobs to meet their needs have concentrated fully on their businesses as their profit margin has improved significantly. As a consequence of the increased population within these host communities, more houses and hostels are being built to accommodate the teeming student population as well as university staff members. The findings also confirm that wealth creation in host communities as an off-shoot of the establishment of tertiary institutions is a piece of common knowledge among its residents.

Although, the presence of the university has led to the establishment of a few banks in the two communities which now provide access for operators of SMSEs in terms of obtaining loan facilities for the growth of their businesses. It was discovered that the presence of the university has not brought about significant rural development even though it has led to economic growth (wealth creation) within the two communities. As already argued by Akinyode et al. (2015), the effects of projects on the community where it is sited could either be positive or negative. Poor road network remains a major problem for commuters both within and outside the university campuses. This has hampered the free movement of students, university staff members, and even business owners in and out of the university. The establishment of the university has also led to the scarcity of accommodation while also contributing to the increase in house rental value within the two communities. Only one additional bank has been established in Oye as a support to the single bank previously operating in the community. This has made it extremely difficult for the teeming population of students, University staff members, and business people to perform bank transactions effortlessly as there is significant pressure on these two small banks. In most cases, stakeholders have to travel to the state capital before major transactions can be completed. The findings also revealed the lack of primary healthcare facilities within the host communities, whereas, access to quality primary health care is an important aspect of wealth, hence, the assertion that Health is Wealth.

From the foregoing, it becomes critical that the establishment of tertiary institutions is strategicallyplanned with the development of host communities in view. This is because the establishment of a tertiary institution in a community will translate to wealth creation by cause and effect. However, it will not necessarily lead to an improved quality of life for the residents in the host communities except in cases where the establishment of the institution is planned with the development of the host communities in-view, such that there is a deliberate attempt to cause economic development. This recommendation is based on the fact that wealth creation/economic growth is just a default impact of the presence of such institutions in any community but there is more than rural communities can benefit just as Rodin (2015) states that:

'A university has the power to be a great agent of change. It has the intellectual, financial, and human resources to take on the challenge of community transformation. It espouses values that embrace shared community, diversity, and engaged discourse (p.24).'

Another key argument for the recommendation is the fact that economic growth (increased-wealth creation) may not necessarily lead to economic development, but economic development always has a high tendency of translating into economic growth as an improved quality of life will result in an improved personal income or household income as the case may be. It is against this backdrop 
that the Nigerian President Muhammadu Buhari recently challenged Vice-Chancellors of Nigeria universities to design policies and programmes that will have a direct bearing on host communities (Nigerian Tribune, 2019).

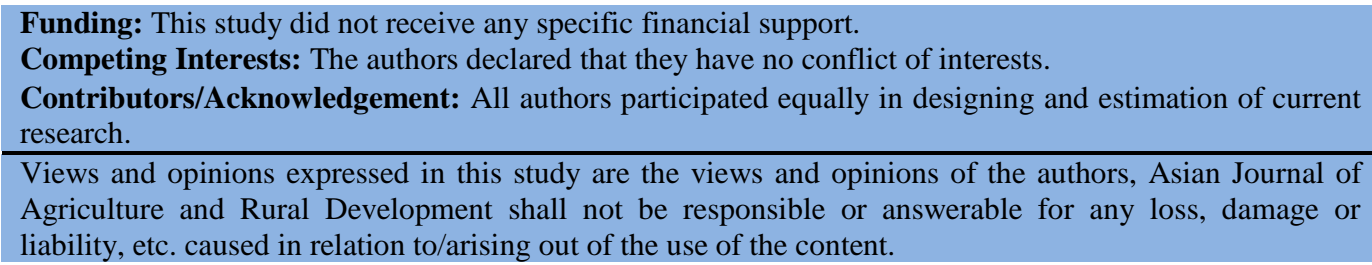

\section{References}

Akinyode, B. F., Tareef, H. K., Abdulahi, S. B., \& Amirmudin, B. U. (2015). Impact of tertiary institutions on house rental value in developing city. Social and Behavioral Sciences, 172, 323-330. doi.org/10.1016/j.sbspro.2015.01.371.

Ali, A. (2010). The role of universities and open and distance learning. Being a text delivered at the 6th Pan-Commonwealth forum on open learning. Developing the community, India, 2428 November 2010.

Awah (2010). The effect of tertiary institutions on host communities: a study of federal college of education, obuuи, cross river state, Nigeria. Ogoja: Onah Printers, Nigeria.

Ayobami, O. (1977). The physical impact of the university of ife on ile ife. An unpublished thesis, Department of Urban and Regional Planning Obafemi Awolowo University Ife.

Blakely-Gray, R. (2020). How much do small business owners make? https://www.patriotsoftware.com/blog/accounting/how-much-do-small-business-ownersmake-average-income/

Ehinmowo, A. A., \& Eludoyin M. O. (2010). The university as a nucleus for growth pole: Example from Akungba - Akoko, Southwest, Nigeria. International Journal of Sociology and Anthropology, 2(7), 149-154.

Fatoki, O. I. (2017). Socio-economic impact of tertiary institutions in Nigeria on host community. American Journal of Management Science and Engineering, 2(6), 176-182. doi.org/10.11648/j.ajmse.20170206.13.

Florida, R. (2004). Cities and the creative class. London and New York: Routledge.

Garlick, S. (2005). The role of higher education institutions in regional development - the case of Australia. Paper presented at a seminar at Karlstad University., Sweden. https://www.oecd/longabstract/.

Hayward, F. M. (2006). Accreditation and quality assurance in African Higher Education: Feelings and lessons learned from a survey of Africa. Paper presented at the 1st international conference of assessing quality of Higher Education. Dec. 11-13 University of Punjab, Lahore.

Kemiki, O., Adeyosoye, A., \& Olusegun, I. (2016). Impact of university on the physical development of host community. Indian Journal of Economics and Development, 4(2), 220236. doi.org/10.15396/afres2014_132.

Liu, Y. S., Yan, B., \& Wang, Y. F. (2016). Urban-Rural development problems and transformation countermeasures in the new period in China. Economic Geography, 7, 1-8.

Maslow, A. H. (1943). A theory of human motivation. Psychological Review, 50(4), 370-396.

Nigerian Tribune (2019). Buhari charges vice-chancellors to impact on host communities. Published in Nigerian Tribune, on July 6, 2019. Retrieved from

https://tribuneonlineng.com/buhari-charges-vice-chancellors-to-impact-on-hostcommunities/

Patrick, J. M., \& Ijah, C. N. (2010). Changes in livelihood: do universities make any difference in their host communities through corporate social responsibilities in Nigeria? British Journal of Education, 8(1), 55-65. doi.org/10.37745/bje/vol8.no1.pp55-65.2020. 
Rodin, J. (2015). The university and urban revival: out of the ivory tower an into the streets. Pennsylvania: University of Pennsylvania Press.

Sen, A. (2001). Development as freedom. Oxford University Press, United Kingdom.

Stokes, K., \& Coomes, P. (1998). The local economic impact of higher education: an overview of methods and practice. AIR Professional File, 67, 1-14.

Tanko, I. M. (2016). An ethnographic case study of a university community engagement programme of a public university in Ghana. An unpublished Ph.D. dissertation, University of Leicester, United Kingdom.

Theobejane, K. S., \& Fatoki, O. (2017). Budgeting and spending habits of university students in South Africa. Gender and Behaviour, 15(3), 9414-9423.

Todaro, M. P., \& Smith, C. (2015). Economic Development (12 ${ }^{\text {th }}$ Edition). PEARSON publishers.

Watson, D. H. (2011). The engaged university: International perspectives on civic engagement. New York and London: Routledge.

Yu, S., Plescac, T. J., \& Zeigenfuse, M. D. (2015). Dynamics of postdecisional processing of confidence. Journal of Experimental Psychology: General, 144(2), 489-510.

Zhang, Y., Vanclaya, F., \& Chena, C. (2019). The social impacts of a stop-start transnational university campus: How the impact history and changing plans of projects affect local communities. Environmental Impact Assessment Review, 77, 105-113. doi.org/10.1016/j.eiar.2019.04.004. 